\title{
Poetry for human rights
}

\section{Laila Sumpton}

This is perhaps not the chapter you were expecting to find in this book, for how can an art have a practical application in the territory of human rights education, campaigning and programming? I would argue that any art can be applied with a human rights-based approach, but that the compact, urgent and linguistically layered nature of poetry suits human rights work well.

I will look at 'Poetry for human rights' from three perspectives: poetry for personal resilience; poetry for human rights education and campaigning; and poetry for voice and empowerment, which charts my own journey into this area of work.

\section{Poetry for personal resilience}

Many people turn to poetry in times of crisis. Either they will read another's work or write their own - trying to condense what is happening to them, make sense of it and bear witness through writing. Being able to write about an experience acknowledges its reality, even when done through metaphor and the mirroring of characters. There is always something of ourselves in our writing, even when we tell someone else's story. On a personal level, being able to turn to writing has enabled me to process life events that would have otherwise disrupted my work and study.

On a professional and academic level, being able to turn to poetry has helped me understand key themes within human rights from genocide, to indigenous rights and refugee law, as it forces you to find the essence of injustice and explain it in words that can be understood outside the lecture hall. This has empowered me as a campaigner, even if the poems I wrote were initially just for myself. Being able to do this was particularly important when working in Bosnia with arts and human rights NGO Most Mira, firstly as an intern, then as a trustee. For the first time in my life I was directly hearing the stories of survivors of concentration camps, visiting mass graves, while at the same time organising youth arts projects and negotiating with local stakeholders. 
Compartmentalising my reactions to the very present history not only enabled me to deliver projects, but also to find a way to take these stories to poetry audiences in the UK who knew little about the conflict. The poems were my awareness raising tools and the very act of writing freed the stories from my mind, allowing me to switch between Bosnia, my job at the time writing up stories about abuse suffered by young homeless people for Depaul UK, and the world of my friends and family.

Building your own resilience in the field of human rights work is crucial; everyone will have their own means. Once I had taught myself how to process information and transform it into poetry I felt better able to try and teach others how to do the same in a way that respects the dignity and agency of those you seek to represent. This led me to think about what a human rightsbased approach to creative campaigning could be, and the responsibility that writers have to handle their subject matter with care and respect. I feel that artists have a responsibility to use their platforms to report the injustices they see, and to do what they can to help others raise their voice, whether they are the survivors or those who are simply aware and looking for a way to speak out.

\section{Poetry for campaigning and human rights education}

Whilst studying at the Institute of Commonwealth Studies, I was lucky to work alongside committed and engaged students who constantly debated human rights issues both in and out of the classroom. Wanting to share this outside of Senate House was something I was passionate about doing, so I set myself a challenge: turning a friend's dissertation about the refugee crisis on the Italian island of Lampedusa into a 30-line poem. How to go about this? The poem needed an approach that did not turn to sentimentality, use dry legal language or shock tactics, but would reach the people who usually switch channel when a news story becomes too distressing. My response lay in mirroring - depicting migration and the search for safety and survival as a natural process through the image of a turtle dragging herself onto a beech to lay her eggs, titled 'Landing on Lampedusa' (Sumpton 2014).

Since writing this poem in 2012, I have led a series of poetry workshops on approaches to creative campaigning with museums, youth groups, universities and a Quaker group looking at women's rights, free speech, and refugee rights through metaphor, hyperbole, satire and through manipulating legal language to make 'found poems.' Supporting learners to create well-crafted poetry that vividly describe human rights stories without resorting to propaganda and soap-box tactics is a campaign tool that helps writers to find their more political voices and to learn how to keep their audiences on side. NGOs and human rights activists can do more to share their stories with artists who can transport these issues to new ears. 
Being a co-editor of the Human Rights Consortium's first poetry anthology In Protest: 150 Poems for Human Rights (Abelvik-Lawson, Hett and Sumpton 2013) taught me so much about the many ways in which human rights issues can be successfully voiced through poetry. We asked for submissions of human rights poetry, not knowing what we would receive, and found ourselves reading 640 entries from 14 different countries tackling a diverse range of issues ranging from land rights in rural India, to child rights in Papua New Guinea, to stories of life under Franco's rule. We set up our own grading scales for successful poems that were well crafted, clearly investigated a human rights issue and brought a fresh perspective to the debates. Over the past few years, it has been great to see how the poetry community can mobilise quickly to fund and create new anthologies whether it is responding to the imprisoning of Pussy Riot (Lucas 2012), in solidarity with the current refugee crisis (Poems For People 2015) or for the general election (Piercey and Wright 2015).

Poets can work as reporters - capturing protests, taking testimony - but they can also work as historians by linking up the stories of the past with themes in our present. In 2012, I and a fellow member of Keats House Poets worked with the Senate House archives to create new poetry for the School of Advanced Study's contribution to the Bloomsbury Festival. We used archive material detailing the University of London's approach to mobilising support for Czech student refugees in the early 1950s, and accounts from the newly arrived students themselves. Forgotten stories of past support can be bought to life through vivid poems to raise awareness of the current refugee crisis and the need for higher education bodies to contribute, as they once did.

Don Patterson, my poetry lecturer at the University of St Andrews, once said that the poem is the only art form that you can carry in your mind in its entirety. It is with this in mind that poetry can be a powerful human rights education tool. Building on several years of writing poems inspired by my work with Most Mira, this summer I led a workshop at their peacebuilding residential programme for young Bosnian and international campaigners with Humanity in Action. The session helped the learners condense what they had learned about peace processes and memorialisation at the community level into short poems, and also helped them to imagine possible futures through focussing on a ruined home that the charity hopes to turn into an arts centre (Sumpton 2015a). This session gave them the space to reflect personally on all of the visits to memorials, reburials and lectures on transitional justice and capture what they needed to tell those who had not experienced this learning for themselves. Poetry helped these campaigners work together and individually to work out what peacebuilding meant to them, and how to use what they had seen to evidence their points in an engaging, lyrical and inspiring way. 


\section{Poetry for voice and empowerment}

At a conference for artists working with young people at London Theatre Bubble, one contributor mentioned something which made me question the validity and ethics of what I consider to be arts projects for social change. They spoke about the danger of artists being accidental therapists in hit and run arts projects. With the reality of funding for both arts and human rights projects being scarce, a one off session, or three to six week projects with vulnerable learners, is becoming common.

Poets sent into schools, prisons, care homes or hospitals to briefly inject creativity into the setting can help learners express themselves and raise their voices about the issues that concern them if this is followed up and part of a holistic program. Very often there is limited or no training on the support needs of the learners of safeguarding, and the artist is presumed to be safe, sensible and sensitive. Often we are, but I have been in workshops where the boundary between poetry facilitator and therapist is blurred. Well planned and supported projects with adequate time funded for reflection, training and planning avoid this, along with a good selection process.

Arts projects can empower learners, helping them express themselves, build confidence and sometimes raise their voices as campaigners. Writers' development agency Spread the Word specialises in taking literature to those who would not normally be able to access it. The right to participation and the right to a cultural life springs to mind as key areas this arts work supports. I have run poetry workshops with dialysis patients at St George's Hospital and in the paediatric wards of the Royal London Hospital and seen first-hand how moods, communication skills, willingness to work with education and health staff and confidence can improve from a few sessions (Sumpton 2015b).

The concentrated, resource light and narrative aspect of poetry sees it as a great tool for helping marginalised members of our society raise their voices and feel like they have some agency over how their stories and perspectives are told. This year I worked with Sense, the UK charity that supports people who are deaf, blind and have multiple and complex disabilities. I was tasked with delivering six months of creative writing workshops with learners in Greenwich and Spalding on the theme of local heritage and rivers, preparing them for a public performance. With the support of excellent freelance project manager Poppy Szaybo and some incredible support staff, I learned the basics of sign language and learned as I went how to creatively engage learners who had never created poetry or stories (Sense 2015). I quickly learned that I would need to write songs, as writing was not an option for the majority of learners. Yet even with all of these new ways of working I was amazed at the changes in confidence, mood management and memory amongst learners. They had never been challenged creatively in this way before or asked to imagine characters, and students who had never spoken to their peers began communicating. Again, 
what may have seemed like a 'decorative' arts project to some, was actually transformative and empowering for the learners. The best advocates are the clients themselves, and if arts workshops can help them grow in confidence and eventually be able to tell their story in a way that suits them, then more campaigns teams should be advocating for these kinds of projects.

From the various projects I have been a part of I have seen how poetry and story writing workshops can help learners understand and feel a sense of ownership over their own stories, and sense the validity of their own voice when they feel disempowered. Poetry can support human rights projects in many different contexts- strengthening voices of protest, voices of witnesses and voices of human rights defenders. Going forward I would ask how can we protect the right to a cultural life for marginalised people and help artists and human rights workers better collaborate? Our work runs off stories and we all need to be powerful storytellers.

Here is the poem I wrote to summarise the experience of the 2015 Project on Peacebuilding residential programme and the stories of survival we heard from Most Mira founder and Omarska camp survivor, Kemal Pervanic.

\author{
Julys near Omarska \\ Sleep was hard to find \\ for the two hundred men \\ locked in a steel mine room- \\ only space to crouch and lean \\ till bodies thinned, faces dwindled. \\ In our July, over 20 years on, \\ a few miles from that mine \\ and the tracks that had towed \\ the village apart \\ it was hotter than any July \\ and sleep was hard to find. \\ Our well ran dry, sheets dank, \\ and flies swarmed in heavy nights \\ riddled with rooster caws \\ and wartime tales that we \\ had woken, that should not sleep- \\ should walk pages and paths \\ spiralling out of here. \\ We had flown in from our various towns \\ found ourselves at a forgotten stop \\ on the most deadly Bosnian road \\ where cars swerve and flowers frame dry ditches. \\ We left all our shoes at the door \\ to contemplate their trails and shelter bugs,
}


as we moved onto the same carpet

we would unravel together.

We were waking up stories people pass-

whilst hay is turned, cats creep up on meat,

and the village rebuilds each year,

it's families returning to repaint doors,

teach children how to tractor lawns,

learn their accent back,

wander new old streets.

We paused and circled graves,

the roll call banners

in steel, marble, cement

with a scattering of wreaths,

stone address cards with only struck out names

re-etched and welded on a roller-deck of loss.

We look for traces, of what was there before

turned over leaves,

found jokes under forgotten bricks,

laughter where washing was hung-

birds soaring through invisible walls, and rebuilt it all in our various tongues to fly and carry home.

\section{Bibliography}

Abelvik-Lawson, H., A. Hett and L. Sumpton (eds.) (2013) In Protest: 150 Poems for Human Rights (London: Human Rights Consortium, School of Advanced Study).

Lucas, C. (2012) 'Catechism: poems for Pussy Riot Live', in English PEN, available at http://www.englishpen.org/events/catechism-poems-for-pussyriot-live/ (accessed 5 Oct. 2015).

Piercey, R. and E. Wright (eds.) (2015) Campaign in Poetry (London: The Emma Press).

Poems For People (2015) 'Poems 4 People Anthology: in solidarity w/ refugees', in Crowd Funder, available at http://www.crowdfunder.co.uk/ poems-4-people-anthology-in-solidarity-wrefugees (accessed 5 Oct. 2015).

Sumpton, L. (2014) 'Laila Sumpton - Landing on Lampedusa', in IndieFeedPerformance Poetry, available at http://indiefeedpp.libsyn.com/lailasumpton-landing-on-lampedusa (accessed 5 Oct. 2015).

- (2015a) 'Day 3: Art and Activism', in Humanity in Action Project on Peacebuilding, available at https://hiapeacebuilding.wordpress. com/2015/07/23/day-3-art-activism/ (accessed 5 Oct. 2015). 
— (2015b) 'Three tips for writers working with hospitals', in Spread the Word, available at http://www.spreadtheword.org.uk/resources/view/three-tipsfor-writers-working-with-hospitals (accessed 30 Sept. 2015).

Sense (2015) 'Poems of the River' an inspiring exhibition at Ayscoughfee Hall Museum, available at https://www.sense.org.uk/content/poems-riverinspiring-exhibition-ayscoughfee-hall-museum (accessed 5 Oct. 2015). 